\title{
Status and Responsibilities Of Academic Librarians
}

By RUSSELL H. SEIBERT

$\mathrm{T}$ THE PREPARATION of librarians, their status, responsibilities, and remuneration are all interrelated. If the acaedmic librarian hopes for faculty status and acceptance-where it is not already a fact - the profession would surely agree that librarians must be willing to meet the same qualitative standards, or their equivalents, as are expected of the faculty at large. And what are these standards? They are of several types:

Educational: It is normally assumed that faculty members will pursue the field of their specialization through the doctorate and show at least minimal skills in the area of scholarly research and publication. To move above the ranks of instructor or assistant professor it is expected that the faculty member will give evidence of his continuing profesional growth as teacher and scholar. The obtaining of a doctorate is meant to be a begining-not an end in itself.

Intellectual: At a library conference at the University of Chicago in August 1948, L. C. Powell said: “On every academic library staff I have any acquaintance with, I can count on a few fingers the number of persons who can establish intellectual cameraderie with the faculty. Until this can be done by a majority of a staff, talk of equal rank with the faculty is a waste of breath." 1 Whether or not this indictment is valid librarians are in a better position to judge than am I. My own experience would not bear it out. But I am confident that intellectual

\footnotetext{
1 Lawrence C. Powell, "Education for Academic Librarianship" in Bernard R. Berelson, ed.: Education for Librarianship; Papers Presented at the Library Conference, University of Chicano, August 16-21, 1948. Chicago: ALA, 1949, pp. 133-146.
}

Mr. Seibert is Vice-President for Academic Affairs, Western Michigan University, Kalamazoo, Mich. This paper was given at the sixth Midwest Academic Librarians' Conference, Western Michigan University, April $14,1961$.

interest, a concern with ideas, is one important mark of a good faculty member.

Professional: The professional man is not concerned with hours. $\mathrm{He}$ is concerned with the performance of certain services and the pursuit of that truth which is directly related to his professional area of interest. An instructor's duty has not been performed when he has prepared for and taught nine, twelve, or fifteen hours of classes and graded the papers. A librarian's duty has not been performed when he has worked thirty, thirty-five, or forty hours in the library. The life of scholarship, the drudgery and the thrill of research, the pursuit of truth; the exchange, the sharpening, the clash of ideas; professional growth-all these are demands that must be met over and above hourly requirements.

A sixty-hour week is not uncommon for a conscientious, dedicated faculty member who feels under self-imposed pressure to grow professionally by seizing every opportunity for study, research, publication, and broad background reading. Few get very far on a forty-hour week. The better professors look upon vacation periods as opportunities for professional advancement as well as times for recreation. Research, writing, study within some well-conceived program of professional growth-these are essentials 
to faculty status, and the unfortunate fact that some faculty members do not meet these standards in no way subtracts from their importance.

Institutional: We ued to have on the faculty a professor who was fond of saying: "I'd be glad to teach for nothing, if only they would pay me for the committee work." Many another has echoed the thought. Committee work of endless types, and endless in time, the sponsoring of sororities, fraternities, campus clubs and organizations, speeches on and off campus are so much with us that, though we may lay waste our powers, such duties are a part of every faculty member's responsibilities.

Faculty members are judged by all these standards. The claims upon them are heavy, time- and energy-consuming, and demanding. It may well be that some librarians would prefer not to be judged by such professional and intellectual standards and would prefer to settle for the less-demanding standards of the technician. But if the librarian aspires to be more than technician he must be willing to be measured by the longer yardstick.

Librarians are far better acquainted with their responsibilities than am I. A broad cultural background and technical competence are both essential to the performance of their duties, but whether the profession is most in need of "the generally trained specialist" or "the specially trained generalist" is a question I gladly leave to others.

One question which I should like to raise, however, is this: How may the librarian assume a more direct responsibility for the education of students? It may be that librarians working closely with other faculty groups can make major contributions to the resolution of the problem we face in providing quality education to large numbers of young Americans. In the years ahead tight budgets may well throw more of the burden of instruction on librarians by placing greater reliance upon library materials as sources of information and media tor independent study. Possibly some librarian, who is both imaginative and creative may develop new techniques and methods by which the library may better serve large numbers of students in the instructional program. At least every administrator should be permitted to have a few such fond hopes.

Economy of operation, whatever the size of the budget, is a major responsibility of every librarian. Library expenditures for books, periodicals, bindings, and salaries represent a very sizable item that must be managed with wisdom and care. The most efficient methods must be constantly sought for handling all the business operations of the library-ordering, processing, circulating, and storing materials. The search for new techniques by which the records of civilized man may be stored in small space must never falter as we face the flood of twentieth-century publications. The accessibility of resources must be balanced against the danger of loss by theft. To carry out these responsibilities calls for a high order of judgment from any librarian.

In any concern for the economical operation of the academic library a question should also be raised about the danger that some professional talent may be employed in ways that are wasteful. In the effort to raise professional standards, is precious professional talent being wasted on positions that could better be filled, or be filled as well, by persons with either less training or a different type of training? Registered nurses today perform many functions that were reserved to M.D.'s a decade ago. Many engineering firms have discovered it is a waste of talent to pay highly trained engineers to do drafting that might actually be better performed by drafting technicians. And so I would ask if professionally trained librarians-whose talents are in short supply-are not sometimes tied to positions that might better be performed by 
business school graduates, for example. With the boldness of ignorance I would suggest that, with this question in mind, a look be taken at the work in the order department and possibly even in the circulation department.

Furthermore, I would hope that we will never reach the point where we assume there is only one route by which professional librarians can be produced and that we would always keep the doors open to other routes of preparation.

Probably judgment of a high order is never more demanded on the part of academic librarians than in the development of a rational and institutionally sound policy on acquisitions. Whatever the character of the college or university, the library must be tailored to fit its ends. If the emphasis is upon research, the library must reflect that function; if the college is primarily for undergraduate study, its collection will again mirror the institution served, but a book collection perfectly balancing all the areas of human knowledge will not be sought. Instead the particular needs of particular faculty members and students must be met. The brilliant research scholar, whose pioneer work brings honor and prestige upon his institution as well as upon himself, may need special assistance. To determine whether or not his extensive requests for materials are justified is no mean art.

The academic librarian must also be alert to the development of new fields of importance in a day of rapid change. $\mathrm{He}$ must cultivate campus relationships in a way that will increase each depart- ment's sense of responsibility for library acquisitions. He must learn to cooperate with the specialist, moderate the demands of the fanatic, prod those departments that suffer from limited vision, and husband resources as wisely as possible.

I said earlier that every administrator should be permitted a few fond hopes. The fondest of those hopes is the dream of a library staffed with perfect librarians: librarians who love books and the contents between their covers; librarians burning with unsatisfied intellectual curiosity; librarians filled with the contagious enthusiasm for learning that will spark a student's interest without repelling him with too much bookish detail; librarians who are the soul of helpfulness, sensitive to the limits of, as well as the need for, assistance; librarians who are quietspoken and courteous, as respectful of those who are reading or studying as the mortician of the bereaved or the young mother of a sleeping child.

Such librarians will make the library a place where all who enter sense that it is more than a pleasant place to meet the girl friend on a cold day-as worthy and important a goal as the latter may be; where the student, be he undergraduate or faculty member, feels welcome; where working conditions are conducive to study and research and where students sense the gravity and the delight of learning.

With such a library, faculty members and classrooms could be reduced to a minimum and administrators be nearly eliminated, for learning would have become a thing of beauty and a joy forever.

\section{Gormley to Succeed Harwell}

Mark M. Gormley has been appointed Executive Secretary of ACRL to replace Richard Harwell who leaves at the end of July. Mr. Gormley will be working as a member of the ACRL staff at the Cleveland conference and will begin his duties at Headquarters on September 1. A sketch about Mr. Gormley appears in this issue's Personnel. 